University of Nebraska - Lincoln

DigitalCommons@University of Nebraska - Lincoln

USDA National Wildlife Research Center - Staff Publications
U.S. Department of Agriculture: Animal and Plant Health Inspection Service

2006

\title{
Experimental Infection of Fox Squirrels (Sciurus Niger) With West Nile Virus
}

\author{
J. Jeffrey Root \\ Paul T. Oesterle \\ Colorado State University - Fort Collins \\ Nicole M. Nemeth \\ Colorado State University - Fort Collins \\ Kaci Klenk \\ Colorado State University - Fort Collins \\ Daniel H. Gould \\ Colorado State University - Fort Collins
}

Colorado State University - Fort Collins, jeff.root@aphis.usda.gov

See next page for additional authors

Follow this and additional works at: https://digitalcommons.unl.edu/icwdm_usdanwrc

Part of the Environmental Sciences Commons

Root, J. Jeffrey; Oesterle, Paul T.; Nemeth, Nicole M.; Klenk, Kaci; Gould, Daniel H.; Mclean, Robert G.; Clark, Larry; and Hall, Jeffrey S., "Experimental Infection of Fox Squirrels (Sciurus Niger) With West Nile Virus" (2006). USDA National Wildlife Research Center - Staff Publications. 1026.

https://digitalcommons.unl.edu/icwdm_usdanwrc/1026

This Article is brought to you for free and open access by the U.S. Department of Agriculture: Animal and Plant Health Inspection Service at DigitalCommons@University of Nebraska - Lincoln. It has been accepted for inclusion in USDA National Wildlife Research Center - Staff Publications by an authorized administrator of DigitalCommons@University of Nebraska - Lincoln. 


\section{Authors}

J. Jeffrey Root, Paul T. Oesterle, Nicole M. Nemeth, Kaci Klenk, Daniel H. Gould, Robert G. Mclean, Larry Clark, and Jeffrey S. Hall 


\title{
EXPERIMENTAL INFECTION OF FOX SQUIRRELS (SCIURUS NIGER) WITH WEST NILE VIRUS
}

\author{
J. JEFFREY ROOT,* PAUL T. OESTERLE, NICOLE M. NEMETH, KACI KLENK, DANIEL H. GOULD, \\ ROBERT G. MCLEAN, LARRY CLARK, AND JEFFREY S. HALL \\ United States Department of Agriculture, Wildlife Services, National Wildlife Research Center, Fort Collins, Colorado; Department of \\ Microbiology, Immunology, and Pathology, Colorado State University, Fort Collins, Colorado
}

\begin{abstract}
Tree squirrels (Sciurus spp.) have exhibited high seroprevalence rates, suggesting that they are commonly exposed to West Nile virus (WNV). Many characteristics of WNV infections in tree squirrels, such as the durations and levels of viremia, remain unknown. To better understand WNV infections in fox squirrels (S. niger), we subcutaneously inoculated fourteen fox squirrels with WNV. Peak viremias ranged from $10^{4.00}$ plaque-forming units (PFU)/mL of serum on day 2 post-infection (DPI) to $10^{4.98} \mathrm{PFU} / \mathrm{mL}$ on $3 \mathrm{DPI}$, although viremias varied between individuals. Oral secretions of some fox squirrels were positive for WNV viral RNA, occasionally to moderate levels (10 ${ }^{3.2} \mathrm{PFU}$ equivalent/swab). WNV PFU equivalents in organs were low or undetectable on $12 \mathrm{DPI}$; gross and histologic lesions were rare. The viremia profiles of fox squirrels indicate that they could serve as amplifying hosts in nature. In addition, viral RNA in the oral cavity and feces indicate that this species could contribute to alternative WNV transmission in suburban communities.
\end{abstract}

\section{INTRODUCTION}

Although West Nile virus (WNV) can infect a wide range of vertebrates, ${ }^{1}$ the recognized transmission cycle of WNV is thought to primarily involve avian amplifying hosts and mosquito vectors. ${ }^{2}$ Many species of wild birds act as vertebrate hosts, ${ }^{3}$ but mammals are generally presumed to serve as deadend hosts. ${ }^{4}$ Despite the apparent lack of mammalian involvement in WNV cycles, Tiawsirisup and others ${ }^{5}$ recently established that eastern cottontail rabbits (Sylvilagus floridanus) develop WNV viremia sufficient to infect some mosquito species, and Tesh and others ${ }^{6}$ noted viremias up to $10^{5} \mathrm{PFU} / \mathrm{mL}$ in experimentally infected golden hamsters (Mesocricetus auratus).

Over the last several years, numerous studies have indicated that many mammalian species have been exposed to WNV. ${ }^{7-12}$ Some experimental infection studies have also been conducted, expanding the knowledge of WNV infection in some mammals. For example, studies in domestic cats showed that prey to predator transmission is possible in mammals, ${ }^{13}$ and golden hamsters may persistently shed WNV in urine for months. ${ }^{6}$ Of interest, high WNV exposure rates have been documented in multiple species of tree squirrels (Sciurus spp.), indicating these species warrant additional scrutiny. ${ }^{11}$

Fox squirrels (Sciurus niger) are common throughout many urban and suburban communities in the United States. The establishment of urban landscapes with a diversity of trees has allowed this species to prosper in many areas of Colorado ${ }^{14}$ and elsewhere. Thus, experimental infection studies of fox squirrels with WNV are necessary to determine their relative susceptibility and pathogenesis of infection ${ }^{15}$ and their potential roles in the transmission of WNV. ${ }^{16}$

We conducted experimental infections of fox squirrels with WNV. Our objective was to monitor morbidity and mortality rates, duration and levels of viremia, viral shedding, presence of WNV RNA in organs, and gross and histologic lesions in WNV-infected fox squirrels. Their potential associations with the public health threat of WNV are discussed.

\footnotetext{
* Address correspondence to J. Jeffrey Root, National Wildlife Research Center, 4101 La Porte Avenue, Fort Collins, CO 80521. E-mail: jeff.root@aphis.usda.gov
}

\section{MATERIALS AND METHODS}

Collections and holding. Eighteen fox squirrels, wildcaught in live traps from the greater Fort Collins area (Larimer County, Colorado), were used in this experiment. On capture, all fox squirrels were dusted for ectoparasites, sexed, weighed, tagged, and a blood sample was drawn from the femoral vein to pre-screen the animals for antibodies to WNV. A second blood sample was drawn from each individual $>3$ weeks later to confirm their WNV serostatus. Fox squirrels were housed one per cage in stainless steel rack cages and provided with a nest box. Sustenance (mixed nuts, whole corn, apples, and oranges) and water were provided $a d$ libitum. After capture, all fox squirrels were allowed to adjust to captivity for $>4$ weeks before the start of the experiment. For the experimental infection, the fox squirrels were transferred to a biosafety level 3 (BSL-3) animal facility and were housed and maintained as described above. All animal methods and housing were approved by the National Wildlife Research Center's Institutional Animal Care and Use Committee.

Experimental protocol. The 18 fox squirrels were randomly divided into two experimental groups: an experimental infection group and a control group. Fourteen fox squirrels were used as experimental test animals. One fox squirrel with preexisting antibodies to WNV was included in this group to explore the effect of pre-existing antibody on pathogenesis. The remaining four animals (all seronegative) were used as control animals. One-half of the fox squirrels (seven experimentally infected and two negative controls) were bled on odd days post infection (DPI), and one-half were processed on even DPIs, so that each animal was bled every other day to limit handling stress. However, on day 12 (termination of the experiment), all surviving fox squirrels were processed and killed.

On day 0 of the experiment, all test animals were subcutaneously inoculated with 1,190 plaque forming units (PFU) of WNV strain NY-99-4132 (one passage in Vero cell culture; originally isolated in 1999 from the brain of an American crow in New York) diluted in $0.1 \mathrm{~mL}$ BA1 medium. The viral titer of the inoculum was determined by Vero cell plaque assay, as described by Bunning and others. ${ }^{17}$ Control animals were inoculated with the same volume of a placebo (BA1 
medium). After inoculation, all fox squirrels were observed daily for signs of illness. One-half of the fox squirrels $(N=9)$ were bled, swabbed, and weighed each DPI (e.g., each animal was handled every other day); urine and feces were collected opportunistically.

Blood was placed in Microtainer ${ }^{\mathrm{TM}}$ tubes and kept on wet ice until centrifuged (usually 1 hour after initial collection; $\sim 16,000 \mathrm{~g}$ for 10 minutes). Swabs were placed in $1.25 \mathrm{~mL}$ of BA1 medium and kept on wet ice until storage. All samples were stored at $-70^{\circ} \mathrm{C}$ in the laboratory.

All animals were killed on 12 DPI with one exception (one squirrel was killed on 2 DPI because of hind limb paralysis), and necropsies were performed immediately on death. The following tissues were routinely collected at necropsy for histopathological examination: heart, liver, spleen, kidney, bladder, skeletal muscle, lung, pancreas, distal esophagus, stomach, duodenum, jejunum, ileum, large intestine, cecum, testes (no gonads were collected for females), lymph node (from some individuals), cerebrum, midbrain, cerebellum, brain stem, and spinal cord. Tissues were preserved with $10 \%$ buffered formalin, embedded in paraffin, sectioned at $5 \mu \mathrm{m}$, and stained with hematoxylin and eosin. In addition, a portion of select organs (e.g., brain, liver, spleen, lung, heart, kidney, bladder) and urine were frozen at $-70^{\circ} \mathrm{C}$ in cryovials for reverse transcriptase-polymerase chain reaction (RT-PCR) analyses. All animal carcasses were incinerated within the BSL-3 facility.

Serology. Epitope-blocking ELISAs using a WNV monoclonal antibody (3.1112G, a WNV-specific antibody that detects an NS1 epitope) were performed using established methods. ${ }^{4}$ Because this assay has been shown to have excellent sensitivity and specificity for WNV antibodies in fox squirrel $\operatorname{sera}^{11}$ (J. J. Root and others, unpublished data) and because of the nature of this study (e.g., an experimental infection), plaque reduction neutralization tests were not performed.

RT-PCR and plaque assays. RNA isolations were attempted from serum, swabs, organs, urine, and feces using the QIAamp Viral RNA Mini Kit (Qiagen, Valencia, CA). For organs, only a subset of the squirrels were tested, which included both test and control animals. The Taqman One-Step
RT-PCR system (Applied Biosystems, Foster City, CA) and the method of Lanciotti and others ${ }^{18}$ were used to quantify WNV RNA based on standard curves generated from viral stocks of known titer. Because of the importance of accurate viremia data to assess the reservoir potential of fox squirrels and the tendency of our RT-PCR system to underestimate viral quantities in samples (J. S. Hall, personal observation), plaque assays were conducted on serum. For quantification of virus in serum samples and virus inoculum administered to the squirrels, Vero cell monolayers in 6-well plates were inoculated in duplicate with $0.1 \mathrm{~mL}$ of sample per well. After 1 hour of incubation at $37^{\circ} \mathrm{C}$, the cells were overlaid with 3 $\mathrm{mL} /$ well of $0.5 \%$ agarose in MEM medium supplemented with $1 \%$ bovine serum albumin, $250 \mathrm{mg} / \mathrm{L}$ sodium bicarbonate, $29.2 \mathrm{mg} / \mathrm{L}$ L-glutamine, $1 \mathrm{mg} / \mathrm{L}$ fungizone, 100 units $/ \mathrm{mL}$ penicillin, $100 \mathrm{mg} / \mathrm{L}$ streptomycin, $50 \mu \mathrm{L}$ gentamicin, and 2.5 $\mu \mathrm{g}$ amphotericin $\mathrm{B} / \mathrm{mL}$ in $50 \mathrm{mmol} / \mathrm{L}$ Tris, $\mathrm{pH}$ 7.6. Two days later, cells were overlaid with $3 \mathrm{~mL}$ of $0.5 \%$ agarose with 0.004\% neutral red dye (Sigma Chemical Corp, St. Louis, MO). Viral plaques were counted on the third and fourth days of incubation. The limit of detection of the virus plaque assay was $10^{1.7} \mathrm{PFU} / \mathrm{mL}$.

\section{RESULTS}

Morbidity and mortality. Seventeen fox squirrels survived to day 12 of the experiment, whereas one was killed on 2 DPI because of progressive hind limb paralysis first evident on 1 DPI. All other fox squirrels $(N=17)$ appeared clinically normal up to 12 DPI.

Viremia profiles. Of the 14 experimentally infected fox squirrels, 13 developed detectable viremia (Table 1). The squirrel that failed to develop a viremic response to WNV infection (squirrel 410) had pre-existing antibodies to WNV reactive with an NS1 epitope, indicating that this squirrel also had protective immunoglobulin. Viremia was first detected at $\geq 10^{1.7} \mathrm{PFU} / \mathrm{mL}$ on day $2 \mathrm{DPI}$ in all experimentally infected squirrels sampled that day and was undetectable by plaque assay by 6 DPI (i.e., $\leq 10^{1.7}$ PFU/mL; Table 1 ; Figure 1 ). Peak viremia titers occurred from 2 to 4 DPI (Figure 1), with peak viremias up to $10^{4.98} \mathrm{PFU} / \mathrm{mL}$ of serum (Table 1 ). Of interest,

TABLE 1

Viral titers, oral shedding, and antibody status of WNV in experimentally infected fox squirrels (S. niger)

\begin{tabular}{|c|c|c|c|c|c|c|c|}
\hline \multirow[b]{2}{*}{ Squirrel } & \multicolumn{3}{|c|}{ Viremia* } & \multicolumn{3}{|c|}{ Oral shedding ${ }^{\dagger}$} & \multirow{2}{*}{$\frac{\text { Antibodies }}{\text { Day first detected }}$} \\
\hline & Peak titer & Peak DPI & Range DPI & Peak titer & Peak day & Range DPI & \\
\hline 401 & 3.81 & 3 & $3-5$ & 2.10 & 5 & 5 & - \\
\hline 402 & 4.98 & 3 & 3 & - & - & - & 9 \\
\hline 403 & 4.55 & 4 & $2-4$ & 2.80 & 8 & $4-8$ & 10 \\
\hline 408 & 4.00 & 2 & $2-4$ & 2.40 & 8 & $4-8$ & 10 \\
\hline 410 \$ & - & - & - & - & - & - & $<0$ \\
\hline $411 \S$ & 3.02 & 2 & 2 & - & - & - & - \\
\hline 412 & 4.88 & 3 & 3 & 2.80 & 5 & $3-9$ & 9 \\
\hline 413 & 3.76 & 4 & $2-4$ & 1.50 & 8 & $6-8$ & 10 \\
\hline 414 & 4.20 & 3 & 3 & 2.10 & 5 & $3-7$ & 9 \\
\hline 415 & 4.13 & 3 & 3 & 1.30 & 7 & 7 & 9 \\
\hline 417 & 4.29 & 4 & $2-4$ & 2.10 & 6 & 6-10 & 10 \\
\hline 418 & 3.69 & 4 & $2-4$ & 2.30 & 6 & $4-8$ & 8 \\
\hline 419 & 4.08 & 2 & $2-4$ & 3.20 & 10 & $4-10$ & 8 \\
\hline 420 & 3.97 & 3 & 3 & 1.70 & 5 & $5-7$ & 9 \\
\hline
\end{tabular}

* Viremia as determined by plaque assays $\left(\log _{10} \mathrm{PFU} / \mathrm{mL}\right)$.

$\dagger$ Oral shedding (PFU equivalent) as determined by RT-PCR.

\$ Animal had pre-existing antibodies to WNV

$\S$ Killed on 2 DPI. 


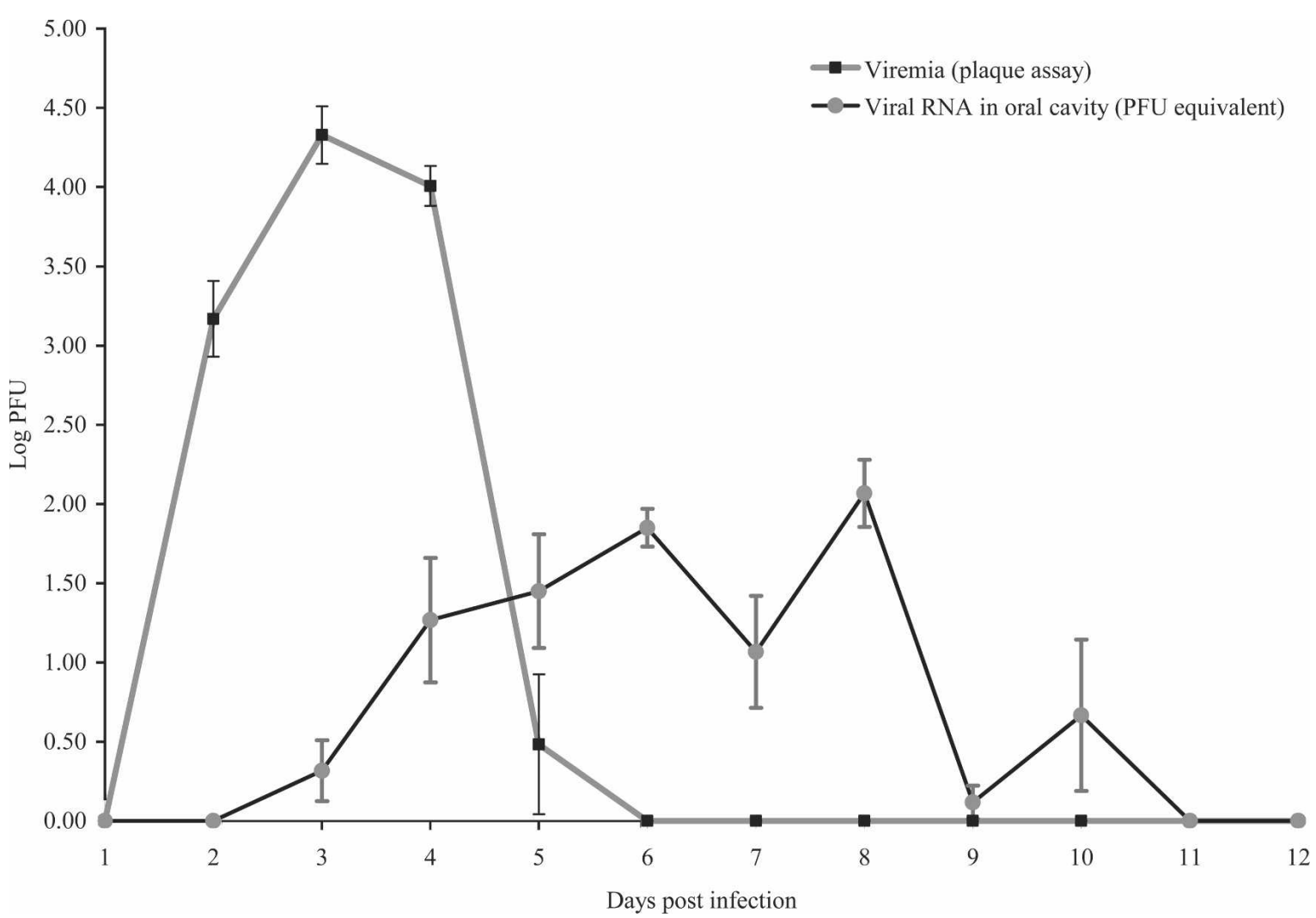

FIGURE 1. Mean daily viremia $( \pm$ SE) and RT-PCR PFU equivalents $( \pm$ SE) for oral swab samples. Control and a single fox squirrel with pre-existing antibodies are not included in the figure.

WNV RNA was still detectable in the serum of one fox squirrel on $12 \mathrm{DPI}$, albeit at a low level $\left(10^{1.3} \mathrm{PFU}\right.$ equivalent/mL serum, data not shown).

Indirect transmission. No evidence of indirect transmission was noted during this study (e.g., all control animals remained seronegative and never developed detectable viremias), even though they were housed in cages adjacent to unfiltered cages containing experimentally infected fox squirrels.

Antibody detections. WNV antibodies were first detected by 8 DPI in two individuals. By 12 DPI, an antibody response was detected in all but one experimentally infected fox squirrel (12/13) without pre-existing antibodies. The individual in question was only slightly less than the $30 \%$ inhibition threshold for being considered positive. ${ }^{4}$ Occasionally, antibodypositive individuals $(N=4)$ reverted to borderline antibody negative status on subsequent days, failing to yield the inhibition threshold mentioned above.

Oral swabs, urine, feces, and organs. WNV RNA was detected in the oral swabs of some, but not all, experimentally infected fox squirrels and was never detected before 3 DPI (Table 1). When RNA was detected (e.g., 11/14 squirrels), it was occasionally found at relatively high levels (e.g., $10^{3.2}$ PFU equivalent/swab), even up to 10 DPI (Table 1 ). Few of the opportunistically collected urine samples yielded RNApositive results. However, on $12 \mathrm{DPI}$, one urine sample yielded $10^{2.7} \mathrm{PFU}$ equivalent $/ \mathrm{mL}$ of urine. Several of the opportunistically collected fecal samples were RT-PCR positive. Positive fecal samples were obtained between 4 and 10 DPI and never were $>10^{3.0} \mathrm{PFU}$ equivalent/sample. Of interest, one fecal sample was $10^{2.6} \mathrm{PFU}$ equivalent/fecal pellet on day
10 DPI. Overall, 50\% (11/22) of opportunistically collected fecal samples were WNV RNA positive. Of the organs tested (i.e., brain, liver, spleen, lung, heart, and kidney), all yielded evidence of WNV RNA in at least one tested $(N=4)$ experimentally infected fox squirrel on day 12 DPI. However, the PFU/sample equivalents were extremely low $\left(<10^{0.9} \mathrm{PFU}\right.$ equivalent $/ 0.15 \mathrm{~g}$ of organ in $140 \mu \mathrm{L} \mathrm{BA} 1)$.

Gross pathology. No gross lesions were observed in 16 of the 17 fox squirrels necropsied on 12 DPI, and all were in good body condition. One squirrel (401) had diffuse cortical pitting on both kidneys. The squirrel killed on 2 DPI was moderately emaciated at necropsy, but all organs appeared grossly normal.

Microscopic lesions. Of the tissues examined, lesions were observed in heart, kidney, brain, and liver. One myocardial lesion pattern was focal to regionally diffuse fibrosis, sometimes accompanied by vacuolation. This pattern was observed in 4 of 14 of the infected squirrels and 0 of 4 controls. A second myocardial lesion pattern was mild, focal mononuclear leukocyte infiltration within the myocardium; this pattern was observed in 2 of 14 infected squirrels and none of the controls. A renal lesion pattern was observed in both infected (3/14) and uninfected controls (1/4) and involved mild to severe radially arranged cortical lymphocytic infiltration and fibrosis associated with nephron loss. In some cases, these kidneys had an irregular cortex surface with indentations where areas of scarring radiated toward the medulla. One infected squirrel had non-suppurative encephalitis affecting the cerebral cortex and brainstem, characterized by multifocal gliosis and lymphocytic perivascular cuffing. Liver 
lesions involved mild to moderate periportal mononuclear leukocyte accumulation and were observed in 4 of 14 infected squirrels and 3 of 4 uninfected controls, although inflammatory areas were generally more common in infected (5-10 observations per $5 \times$ field) versus non-infected (1-4 observations per $5 \times$ field) squirrels. Incidental lesions included a renal venular thrombus associated with mononuclear leukocyte accumulation in one of the infected squirrels, focal mononuclear leukocyte myositis in one of the infected squirrels, and multifocal, granulomatous pneumonia in one of the uninfected controls. One infected squirrel had evidence of WNV antibodies in response to natural infection before experimental challenge with WNV; this animal had no microscopic lesions. The squirrel killed on 2 DPI had moderate multifocal myocardial scarring, whereas all other tissues were histologically normal.

\section{DISCUSSION}

Tree squirrels are one of several free-ranging mammal species in North America for which evidence of WNV exposure has been published. ${ }^{8,11,19}$ However, multiple investigators have obtained data from dead and moribund squirrels. ${ }^{15,16}$ Thus, the survival rates of experimentally infected fox squirrels (13/14) in this study are somewhat surprising. Only a single fox squirrel yielded signs of illness during this study (hind limb paralysis). The timing of the paralysis (1 DPI) and the relative lack of microscopic lesions suggest that the clinical signs observed were not caused by WNV infection. Our observation of high survival with little or no obvious signs of disease in fox squirrels is consistent with that reported for eastern cottontail rabbits ${ }^{5}$ and dogs. ${ }^{13}$ In contrast, Tonry and others ${ }^{20}$ indicated that experimentally infected golden hamsters began to show clinical signs of infection around 7 days DPI, and by day 16 , surviving animals began to appear normal (e.g., active, curious, feeding well). Furthermore, some experimentally infected cats showed mild, non-neurologic signs of disease, ${ }^{13}$ whereas 1 of 12 experimentally infected horses showed severe clinical disease by 9 DPI. ${ }^{17}$

Similar to observations in naturally infected, clinically ill tree squirrels, we observed very few gross lesions in experimentally infected fox squirrels. ${ }^{15,16}$ However, we observed no clinical signs in infected squirrels and few microscopic lesions that could be definitively attributed to WNV infection. Naturally infected, clinically ill tree squirrels in Illinois commonly exhibited microscopic brain lesions (16/16) and lymphocytic myocarditis (12/16), with mild hepatic necrosis a less common finding (4/16) ${ }^{15}$ In another study of three naturally infected fox squirrels in Michigan, ${ }^{16}$ the most consistent lesion pattern was multifocal lymphoplasmacytic nephritis; one adult squirrel also had severe myocardial lesions and moderate nonsuppurative meningoencephalitis.

It is difficult to attribute most of the lesions observed in our study to WNV infection because of the presence of these patterns in uninfected control squirrels. Myocardial scarring only occurred in infected fox squirrels, but one of these was killed on 2 DPI because of unrelated reasons, which is inconsistent with WNV as the cause for this lesion pattern. Nonetheless, mild mononuclear leukocyte myocarditis and nonsuppurative encephalitis are lesion patterns that, although rare in infected squirrels in our study, may have been attrib- utable to WNV infection. These lesions were mild and would not be considered a cause for clinical disease. In general, fox squirrels in this study were not adversely affected by WNV infection, and based on our observations, all would have been expected to survive infection. In addition, because all of the squirrels in this study were wild-caught, their clinical histories are unknown, and some or all of the lesions observed could have been present before experimental WNV infection.

Komar and others ${ }^{21}$ considered birds that developed viremias of $10^{5.0} \mathrm{PFU} / \mathrm{mL}$ or greater WNV reservoir competent for select mosquito species, whereas bird species that did not develop this level of viremia were considered reservoir incompetent. However, blood meals from lower levels of viremic blood may be sufficient to infect some mosquito species, although possibly at a lower infection rate. ${ }^{13}$ For example, Tiawsirisup and others ${ }^{22}$ reported that some mosquito species became infected after feeding on chickens with moderately high viremia levels $\left(10^{4.5} \mathrm{CID}_{50} / \mathrm{mL}\right)$. Thus, the WNV viremia levels reported herein for fox squirrels may be sufficient to infect certain mosquito species, suggesting that they may be reservoir competent in certain situations.

Results from a recent WNV experimental infection study indicated that one mammalian species, the golden hamster, can develop persistent shedding of WNV in urine for up to 8 months. ${ }^{6}$ If this were the case in fox squirrels, a possible alternative mechanism of the WNV transmission in this species could be the passage of virus-laden urine from squirrel-tosquirrel. Obviously, this would require close contact. Furthermore, in a natural setting, WNV may be shed only during certain times (e.g., stress-induced). For example, J. J. Root and others (unpublished data) failed to detect WNV RNA in the urine of a small number of wild-caught seropositive fox squirrels; however, 9 of 19 urine samples collected opportunistically in this study were positive for WNV RNA, although typically at low titer equivalents $\left(10^{2.7} \mathrm{PFU}\right.$ equivalent $/ \mathrm{mL}$ maximum). Thus, if fox squirrels were to persistently or intermittently shed WNV in urine, newly infected individuals could become viremic during various times of the year, possibly contributing to atypical WNV cycles.

Unlike dogs, cats, ${ }^{13}$ and horses,${ }^{17}$ some fox squirrels apparently shed WNV orally for reasonably long periods of time, albeit at relatively low levels. For example, one experimentally infected fox squirrel shed $10^{2.8}$ and $10^{2.5} \mathrm{PFU} / \mathrm{swab}$ equivalent titers on 5 and $7 \mathrm{DPI}$, respectively. Considering that fox squirrels are highly peridomestic and often forage at bird feeders, WNV shed orally could be of epidemiologic importance, because experimental studies have indicated that transmission of WNV among birds may be possible through WNV-laden oral discharges. ${ }^{23}$ Interestingly, fox squirrels are thought to be somewhat communal in their use of nests and possibly of winter food stores. ${ }^{24}$ Thus, WNV-laden oral secretions could pose a potential means of transmission among fox squirrels, dependent on the time of year they were associated with each other (e.g., potential of aggressive encounters during the breeding season).

This study suggests fox squirrels could be of epidemiologic importance for WNV transmission cycles. First, peak viremias of this peridomestic mammal may be sufficient to infect select mosquito species. Second, unlike most other mammals tested to date, they likely shed WNV orally and in other secretions such as feces. Third, fox squirrels and other tree squirrels are well documented to be exposed to WNV at exceptionally high 
levels, likely a facet of their behavioral ecology. ${ }^{11}$ Fourth, the establishment of urban landscapes with a diversity of trees has allowed this species to prosper in many urban areas. ${ }^{14}$ Thus, their potential importance in the epidemiology of WNV in urban and suburban settings should not be discounted.

Received April 22, 2006. Accepted for publication June 14, 2006.

Acknowledgments: The authors thank H. Sullivan (NWRC) for laboratory assistance, G. Gathright (NWRC), K. Bird (NWRC), R. Swarz (NWRC), and H. Martinez (NWRC) and additional NWRC animal care staff for excellent animal care and both private and public land stewards for logistical assistance. We are greatly indebted to R. Bowen (CSU) for laboratory support, advice, and animal space.

Financial support: Funding for this work was provided by the US Department of Agriculture and the US Centers for Disease Control and Prevention (LC: CDC IAA 03FED12031).

Authors' addresses: J. Jeffrey Root, Paul T. Oesterle, Kaci Klenk, Robert G. McLean, Larry Clark, and Jeffrey S. Hall, National Wildlife Research Center, USDA/APHIS/WS, 4101 La Porte Avenue, Fort Collins, CO 80521, Telephone: 970-266-6000, Fax: 970-266-6138, E-mail: jeff.root@aphis.usda.gov, paul.t.oesterle@aphis.usda.gov, kaci.klenk@aphis.usda.gov, robert.g.mclean@aphis.usda.gov, larry.clark@aphis.usda.gov, and jeffery.s.hall@aphis.usda.gov. Nicole M. Nemeth and Daniel H. Gould, Department of Microbiology, Immunology, and Pathology, Colorado State University, Fort Collins, CO 80523, Telephone: 970-491-6164, Fax: 970-491-0603, E-mail: nnemeth@lamar.colostate.edu and daniel.gould@colostate.edu.

Reprint requests: Dr. Jeff Root, National Wildlife Research Center, 4101 La Porte Avenue, Fort Collins, CO 80521, E-mail: jeff.root@ aphis.usda.gov.

\section{REFERENCES}

1. Centers for Disease Control and Prevention, 1999. Outbreak of West Nile-like viral encephalitis-New York, 1999. MMWR Morb Mortal Wkly Rep 48: 845-849.

2. McLean RG, Ubico SR, Bourne D, Komar N, 2002. West Nile virus in livestock and wildlife. Curr Top Microbiol Immunol 267: 271-308.

3. Ludwig GV, Calle PP, Mangiafico JA, Raphael BL, Danner DK, Hile JA, Clippinger TL, Smith JF, Cook RA, McNamara T, 2002. An outbreak of West Nile virus in a New York City captive wildlife population. Am J Trop Med Hyg 67: 67-75.

4. Blitvich BJ, Bowen RA, Marlenee NL, Hall RA, Bunning ML, Beaty BJ, 2003. Epitope-blocking enzyme-linked immunosorbent assays for detection of West Nile virus antibodies in domestic mammals. J Clin Microbiol 41: 2676-2679.

5. Tiawsirisup S, Platt KB, Tucker BJ, Rowley WA, 2005. Eastern cottontail rabbits (Sylvilagus floridanus) develop West Nile virus viremias sufficient for infecting select mosquito species. Vector Borne Zoonotic Dis 5: 342-350.

6. Tesh RB, Siirin M, Guzman H, Travassos da Rosa APA, Wu X Duan T, Lei H, Nunes MR, Xiao S-Y, 2005. Persistent West Nile virus infection in the golden hamster: Studies on its mechanism and possible implications for other flavivirus infections. J Infect Dis 192: 287-295.

7. Anderson JF, Vossbrinck CR, Andreadis TG, Iton A, Beckwith WH III, Mayo DR, 2001. Characterization of West Nile virus from five species of mosquitoes, nine species of birds, and one mammal. Ann N Y Acad Sci 951: 328-331.

8. Kramer LD, Bernard KA, 2001. West Nile virus infection in birds and mammals. Ann N Y Acad Sci 951: 84-93.

9. Farajollahi A, Panella NA, Carr P, Crans W, Burguess K, Komar N, 2003. Serologic evidence of West Nile virus infection in black bears (Ursus americanus) from New Jersey. J Wildl Dis 39: 894-896.

10. Dietrich G, Montenieri JA, Panella NA, Langevin S, Lasater SE, Klenk K, Kile JC, Komar N, 2005. Serologic evidence of West Nile virus infection in free-ranging mammals, Slidell, Louisiana, 2002. Vector Borne Zoonotic Dis 5: 288-292.

11. Root JJ, Hall JS, McLean RG, Marlenee NL, Beaty BJ, Gansowski J, Clark L, 2005. Serologic evidence of exposure of wild mammals to flaviviruses in the central and eastern United States. Am J Trop Med Hyg 72: 622-630.

12. Santaella J, McLean R, Hall JS, Gill JS, Bowen RA, Hadow HH, Clark L, 2005. West Nile virus serosurveillance in Iowa whitetailed deer (1999-2003). Am J Trop Med Hyg 73: 1038-1042.

13. Austgen LE, Bowen RA, Bunning ML, Davis BS, Mitchell CJ, Chang G-JJ, 2004. Experimental infection of cats and dogs with West Nile virus. Emerg Infect Dis 10: 82-86.

14. Fitzgerald JP, Meaney CA, Armstrong DM, 1994. Mammals of Colorado. Niwot, CO: University Press of Colorado.

15. Kiupel M, Simmons HA, Fitzgerald SD, Wise A, Sikarskie JG, Cooley TM, Hollamby SR, Maes R, 2003. West Nile virus infection in eastern fox squirrels (Sciurus niger). Vet Pathol 40: 703-707.

16. Heinz-Taheny KM, Andrews JJ, Kinsel MJ, Pessier AP, Pinkerton ME, Lemberger KY, Novak RJ, Dizikes GJ, Edwards E, Komar N, 2004. West Nile virus infection in free-ranging squirrels in Illinois. J Vet Diagn Invest 16: 186-190.

17. Bunning ML, Bowen RA, Cropp CB, Sullivan KG, Davis BS Komar N, Godsey MS, Baker D, Hettler DL, Holmes DA Biggerstaff BJ, Mitchell CJ, 2002. Experimental infection of horses with West Nile virus. Emerg Infect Dis 8: 380-386.

18. Lanciotti RS, Kerst AJ, Nasci RS, Godsey MS, Mitchell CJ, Savage HM, Komar N, Panella NA, Allen BC, Volpe KE, Davis BS, Roehrig JT, 2000. Rapid detection of West Nile virus from human clinical specimens, field-collected mosquitoes, and avian samples by a TaqMan reverse transcriptase-PCR assay. J Clin Microbiol 38: 4066-4071.

19. Centers for Disease Control and Prevention, 2003. West Nile virus activity-United States, November 20-25, 2003. MMWR Morb Mortal Wkly Rep 52: 1160

20. Tonry JH, Xiao S-Y, Siirin M, Chen H, Travassos Da Rosa APA, Tesh RB, 2005. Persistent shedding of West Nile virus in urine of experimentally infected hamsters. Am J Trop Med Hyg 72 320-324.

21. Komar N, Langevin S, Hinten S, Nemeth N, Edwards E, Hettler D, Davis B, Bowen R, Bunning M, 2003. Experimental infection of North American birds with the New York 1999 strain of West Nile virus. Emerg Infect Dis 9: 311-322.

22. Tiawsirisup S, Platt KB, Evans RB, Rowley WA, 2004. Susceptibility of Ochlerotatus trivittatus (Coq.), Aedes albopictus (Skuse), and Culex pipiens (L.) to West Nile virus infection. Vector Borne Zoonotic Dis 4: 190-197.

23. McLean RG, Ubico SR, Docherty DE, Hansen WR, Sileo L, McNamara TS, 2001. West Nile virus transmission and ecology in birds. Ann N Y Acad Sci 951: 54-57.

24. Schmidly DJ, 1994. The Mammals of Texas: Revised Edition. Austin, TX: University of Texas Press. 